\section{REVISTA CIENTÍFICA RURAL}

ISSN: $1413-8263 \quad 2525-6912$
Revista Técnico-Científica
(

EDIUACANP

turcomp

\title{
EFFECT OF SEEDS DRESSINGON THE INITIAL ESTABLISHMENT OF IRRIGATED RICE IN DIFFERENT TEMPERATURES AND SOWING PERIODS
}

\author{
Thaís D Avila Rosa ${ }^{1}$, Diogo Balbé Helgueira ${ }^{1}$, Marlon Ouriques Bastiani ${ }^{1}$, Ivan Ricardo Carvalho², \\ Mauro Mesko Rosa ${ }^{1}$, Cédrick Benetti ${ }^{1}$, Andréia da Silva Almeida ${ }^{1}$, Luis Antonio de Avila ${ }^{1}$, Vinícius \\ Jardel Szareski ${ }^{1}$, Giordano Gelain Conte ${ }^{1}$, Francisco Amaral Villela ${ }^{1}$ \\ 1Federal University of Pelotas - Seed Science and Technology. Avenida Eliseu Maciel, s/n - 96001-970 - Capão Leão, Rio \\ Grande do Sul - Brasil; \\ ${ }^{2}$ Department of Agrarian studies, Regional Northwest Universidad of Rio Grande do Sul - 3000 - Comercio Street, ljuí, RS, \\ 98700-000, Brasil. E-mail: carvalho.irc@gmail.com
}

\begin{abstract}
The study aimed to evaluate the effects of seeds dressing in the initial establishment of irrigated rice and in the tolerance to herbicides when submitted to low temperatures. The study comprehended two experiments, where the first stage was realized at the Laboratory of Seeds and Technology of the Plants Science Department of the Federal University of Pelotas. Experiment 1: Effect of different seed dressings under the physiologic potential of irrigated rice seeds and experiment 2: Effect of the seeds dressing in the initial establishment of irrigated rice in different sowing seasons in field. The treatment with dietholate and the combining of dietholate + fipronil + carboxina + tiram, negatively influenced the germination and the vigor tests in both temperatures, decreasing the physiologic performance of rice seeds in lab. When taken to field, the seeds dressing did not influence the analyzed factors, being dependent of the herbicide applying and the sowing season. Besides presenting phytotoxicity, the rice plants presented detoxification power from the herbicide, being possible to analyze this fact, since there was higher number of tillers, resulting in higher number of panicles resulting in higher productivities.
\end{abstract}

Key- words: Grown and desenvolviment of plant; managements of plants; production of seed.

\section{EFEITO DO TRATAMENTO DE SEMENTES NO ESTABELECIMENTO INICIAL DE ARROZ IRRIGADO EM DIFERENTES TEMPERATURAS E PERÍODOS DE SEMEADURA}

RESUMO: O estudo teve como objetivo avaliar os efeitos do curativo de sementes no estabelecimento inicial de arroz irrigado e na tolerância a herbicidas quando submetidos a baixas temperaturas. $O$ estudo compreendeu dois experimentos, onde a primeira etapa foi realizada no Laboratório de Sementes e Tecnologia do Departamento de Ciências Vegetais da Universidade Federal de Pelotas. Experiência 
1: Efeito de diferentes curativos de sementes sob o potencial fisiológico de sementes de arroz irrigado e experimento 2: Efeito do curativo de sementes no estabelecimento inicial de arroz irrigado em diferentes épocas de semeadura em campo. O tratamento com dietolato e a combinação de dietolato + fipronil + carboxina + tiram influenciaram negativamente os testes de germinação e vigor em ambas as temperaturas, diminuindo o desempenho fisiológico das sementes de arroz em laboratório. Quando levado para o campo, o curativo das sementes não influenciou os fatores analisados, sendo dependente da aplicação do herbicida e da estação de semeadura. Além de apresentar fitotoxicidade, as plantas de arroz apresentaram poder de desintoxicação do herbicida, sendo possível analisar esse fato, pois houve maior número de perfilhos, resultando em maior número de panículas, resultando em maior produtividade.

Palavras- chave: Cultivo e desenvolvimento de planta; manejos de plantas; produção de sementes.

\section{INTRODUCTION}

The state of Rio Grande do Sul stands out as the main rice producer in Brazil, through the cultivation of irrigated rice in an area of 1,1 million hectares, and productivity of 7,85 tons per hectare (CONAB, 2018). The rice fields in Rio Grande do Sul have a fundamental importance in the agro-economic scenario of the state, being responsible for about $61 \%$ of the total rice produced in Brazil (SOSBAI, 2018). However, the crop suffer stresses that can compromise its yield potential, among them there are biotic factors, such as pests and weeds, and abiotic as temperature and luminosity.

In this manner, it has been sought alternatives that allows a better use of the genetic potential of cultivars, and the reduction of production costs. An alternative that has stood out in the last years is the sowing in the beginning of the preferential season. It proportionate gains in yield, allied to the search of new alternatives that allows to the crops, higher tolerance to stress factors and consequently develop more vigorous in good conditions, what permits better chances of achieve higher yields (Almeida et al., 2013; Szareski et al., 2016).

In the state of Rio Grande do Sul, the sowing realized in the end of September and beginning of October, synchronizes the period of larger solar radiation (December and January) (SOSBAI, 2018), with the rice reproductive phase. It is an important factor in order to obtain higher productivities, due to the higher efficiency in the nitrogen assimilation during the microsporogenesis stage (pollen formation) and grains filling (Freitas et al., 2008; Szareski et al., 2018).

In the other hand, one of the main problems caused by early sowing is the stress by low temperature, what can reflect in low seeds germination, low initial stand of seedlings, low productivity and reduction in tolerance to herbicides. This fact has been observed mostly in the regions of Campanha and Southern of Rio Grande do Sul, where it is verified that fields early sown present high phytotoxicity caused by herbicides classified as selective (Martini, 2014; Aisenberg et al., 2016).

The herbicides selectivity is key to control weeds and is dependent of the three main factors: the crop, the herbicide and environment. Low temperatures can guide the increase of the concentration of reactive oxygen species (ROS), since it generates negative effects on the crop metabolism (Hashimoto \& Komatsu, 2007). The herbicide metabolism can be directly affected because of this increase (Vila-Aiub et al., 2012), 
fact that is intimately linked to the reduction of tolerance to herbicides, what can cause a decrease in productivity.

Other factor that can limit the irrigated rice yield is the competition with weeds (Lilge et al., 2003). A more effective control of weeds, by herbicides, without severe injuries caused to the crop is desirable. For such, one alternative used is the seed

with protectants, seeking to minimize the phytotoxic effects caused by some herbicides.

Some products possess protectant activity and is related to the increase of the crop tolerance, allowing them to metabolize the chemical product faster thanthe weeds, causing lower damage to the crop (Yazbek et al, 2004).

The seeds dressingis a practice used in order to minimize yield loses caused by pests and diseases that can affect the initial development of crops. This practice is based on the application of chemical products as insecticides, fungicides, growth regulators or micronutrients in seeds in periods that precede the seedling (Koch et al., 2017; Kavalco et al., 2017). Besides the seeds protection offered by the product, studies indicate that may occur an increase in the velocity of seedlings emergence (Almeida et al., 2013; Szareski et al., 2016; Dellagostin et al., 2016; Zanatta et al., 2018).

Many researches assign to some products used for seeds dressing a phytotonic effect, that is, faster development of seedlings, better germination and higher vigor (Almeida et al., 2014; Kehl et al., 2016; Szareski et al., 2018). This effect can be relevant, since the factors as temperature direct regulates the velocity of this process (Marcos Filho, 2015). In front of this context, this study aimed to evaluate the effects of seeds dressing in the initial establishment of irrigated rice and in the tolerance to herbicides when submitted to low temperatures.

MATERIAL AND METHODS

The study comprehended two experiments, where the first stage was realized at the Laboratory of Seeds and Technology of the Plants Science Department of the Federal University of Pelotas (UFPel). The second stage was carried out on field, in a systemized area, in the Palma Agriculture Center (CAP), from the UFPel, during the crop season of 2013/2014. The soil is classified as Solodic Planosol, belonging to the Pelotas mapping unit (EMBRAPA, 2012).

\section{Experiment 1 - Effect of different seed dressings under the physiologic potential of irrigated rice seeds}

The experiment was arranged in factorial scheme 7 (seed dressings) $\times 2$ (temperatures 25 and $17^{\circ} \mathrm{C}$ applied to seedlings development) (Table 1). The cultivar used was IRGA 424 one of the most cultivated in the state of Rio Grande do Sul.

Table1. Products used for seed dressing (SD) in irrigated rice.

Tabela 1. Produtos utilizados para o tratamento de sementes (SD) em arroz irrigado.

\begin{tabular}{ccc}
\hline Dressings & Factor A: & \multicolumn{1}{c}{ Dose } \\
& Active Ingredient in the TS & g i. a. $100 \mathrm{~kg}^{-1}$ \\
\hline 1 & No Dressing & --- \\
2 & Thiamethoxam & 140,0 \\
3 & Dietholate & 600,0 \\
4 & Fipronil & 62,5 \\
5 & GiberellicAcid & 2,0 \\
6 & Carboxina+Tiram & $60,0+60,0$ \\
7 & Dietolate+Fipronil+ Carboxina+Tiram & $600,0+62,5+60,0+60,0$ \\
\hline
\end{tabular}

The seed dressings were realized directly at the seeds with pressurized valve, 24 hours before de experiment placement, being put in plastic bags with five liters of 
capacity, using one $\mathrm{kg}$ of seeds per bag. The used spray volume was $1.5 \mathrm{~L} 100 \mathrm{~kg}^{-1}$ of seeds and, as treat control, it was used distilled water.

The evaluation of the influence of seeds dressing and environmental temperature on different physiologic characteristics of rice seeds were realized through the following analysis:

- Germination Test: realized in four samples of of subsamples of 50 seeds, totalizing 16 experimental units per treat, disposed in paper rolls of three germitest-paper sheet, wetted with distilled water with 2.5 times the paper dry weight. The rolls were transferred to a germination chamber type BOD at $17^{\circ} \mathrm{C}$ and at $25^{\circ} \mathrm{C}$ with photoperiod of 12 hours. The evaluations were realized 14 days after sowing and the results were expressed in percentage of normal seedlings, according the Rules for Seed Analysis (Brasil, 2009).

- First counting of germination: it was performed with the germination test, at five days after sowing, according the RAS (Rules for Seed Analysis), for the temperatures of 25 and $17^{\circ} \mathrm{C}$. The results were expressed in percentage of normal seedlings.

- Index of germination velocity (IGV): it was obtained from the daily counting of germinated seeds (minimum radicular protrusion of 3 and $4 \mathrm{~mm}$ ). The counting were realized until de obtaining of a constant number of germinated seeds. For the calculation of the IGC was used the equation suggested by Popinigis (1985) IVG=N1/D1+N2/D2+Nn/Dn where, N1 = number of emerged plants in the first day; Nn = accumulated number of emerged plants; D1 = first day of counting; Dn = number of counted days after sowing.

- Accelerated aging: the seeds were conditioned in acrylic boxes (mini-chambers), type gerbox with horizontal metallic screen fixed in median position. It was uniformly distributed 50 seeds, for each dressing, over screen and added $40 \mathrm{ml}$ of distilled water (for the obtaining of approximately $100 \%$ of R.U.). Right after, the boxes were closed and conditioned in chamber type BOD, with regulated temperature of $41^{\circ} \mathrm{C}$, were stayed 120 hours. After this aging period, the seeds were allocated in germited paper and put for germination in the same conditions of the germination test in the temperature of 17 and $25^{\circ} \mathrm{C}$, being evaluated in the fifth day after the test installation. The results were expressed in percentage of normal seedlings.

- Cold Test: realized in four subsamples of 50 seeds per sample, distributed in rolls of germitest paper previously wetted with distilled water at the ratio 2,5 times the paper dry weight and submitted to constant temperature. The rolls were covered with plastic bags in order to avoid humidity loss, and maintained in BOD with temperature of $10^{\circ} \mathrm{C}$ for a period of seven days, according methodology proposed by the Vigor Committee of the Internation Seed Testing Association (ISTA, 1995). After this period, the rolls were transferred to germinator at the temperature of 25 and $17^{\circ} \mathrm{C}$, and the results expressed in percentage of normal seedlings, as stated by the Ruler for Seed Analysis (BRASIL, 2009).

- Length of the shoot and root: it was used four replicates of 10 seeds, sowed over germitest paper, being evaluated, after seven days, the radicular and shoot length of normal seedlings, with the assistance of millimeter ruler.

- Mass of seedlings dry matter: it was determined in four replicates of ten seedlings after 14 days, and maintained in paper bags, in kiln at $60^{\circ} \mathrm{C}$, until obtaining constant mass, weighted in precision scale $(0,001 \mathrm{~g})$. The value obtained through the sum of each replicate was divided by the number of seedlings used and the results were expressed in mg.seedling ${ }^{-1}$. 
The data were submitted to variance analysis and, when proved the significance of the treat effect by $F$ test $(p \leq 0,05)$, the treats means were compared by Tukey test $(p \leq 0,05)$.

\section{Experiment 2 - Effect of the seeds dressing in the initial establishment of irrigated rice in different sowing seasons in field.}

The study was carried out on field during the crop season of 2013/2014, in systemized area, at the Palma Agriculture Center (CAP), from the Federal University of Pelotas (UFPel). The experiment was arranged in factorial scheme 7 (products recommended for dressing of rice seeds) $\times 3$ (dressings with herbicides) $\times 2$ (sowing periods), in experimental design of randomized blocks with four replicates (Table 2).

The two sowing periods were defined based on the agro-climatic zoning for rice cultivation in the state of Rio Grande do Sul. The first sowing period was implanted day September 13 (previously to the recommended day) and the second, day October 18 (recommended period).

Table 2. Dressings with herbicides applied in irrigated rice for the control of weeds.

Tabela 2. Curativos com herbicidas aplicados em arroz irrigado para controle de plantas daninha

\begin{tabular}{ccc}
\hline Factor B: & $\begin{array}{c}\text { Registered dose of the } \\
\text { Active Ingredient in post-emergence }\end{array}$ & $\begin{array}{c}\text { p c } \\
(\mathrm{g} \mathrm{i} . \mathrm{a} . \mathrm{ha}-1)\end{array}$ \\
\hline Control & --- & Application period \\
Bispiribaque - sodium & 50 & Post - emergence \\
Profoxidim & 170 & Post - emergence \\
\hline
\end{tabular}

The experimental units were composed by nine sowing lines spaced in $17 \mathrm{~cm}$ by five meters length, totaling $7,65 \mathrm{~m}^{2}$. The soil was prepared in the conventional system. The rice cultivar used was IRGA 424, at the density of $100 \mathrm{~kg}^{\circ}$ of seeds ha-1.

The base fertilizing was of $350 \mathrm{~kg} \mathrm{ha}^{-1}$ of the formula 05-20-30, corresponding to the supplying of $17,5 \mathrm{~kg} \mathrm{ha}^{-1}$ of nitrogen $(\mathrm{N}), 70 \mathrm{~kg} \mathrm{ha}^{-1}$ of $\mathrm{P}_{2} \mathrm{O}_{5}$ and $105 \mathrm{~kg} \mathrm{ha}^{-1}$ of $\mathrm{K}_{2} \mathrm{O}$. The nitrogen broadcast fertilizing was realized with urea (46-00-00) in three steps, being the first application realized in the tillering (V3-V4), with application of $70 \mathrm{~kg} \mathrm{ha}^{-}$ ${ }^{1}$ of nitrogen, the second during the $\mathrm{V} 6$ stage with $30 \mathrm{~kg} \mathrm{ha}^{-1}$ of nitrogen, and the third realized at the first emerging flowers, applying $30 \mathrm{~kg} \mathrm{ha}^{-1}$ of nitrogen. The rest of the cultural traits were performed as technical indications of the research for irrigated rice in the Southern Brasil (SOSBAI, 2018).

The experimental area was suffering of infestation with Echinochloa sp., being the average population of 500 plants $\mathrm{m}^{-2}$. Before the placement of each sowing period, it was realized the area desiccation with the applying of glyphosate in the dose of 1440 g.i.a ha-1. The herbicide dressings were applied in the irrigated rice post-emergence, when weeds were ate the growth stage of V3-V4 (3 to 4 leaves), following the usage recommendations of the fabricant.

The application was realized with the assistance of a precision costal sprayer, pressurized with $\mathrm{CO}_{2}$, equipped with bar with four flat fan nozzle, series 110-02, spaced in $0,5 \mathrm{~m}$, calibrated to apply a spray mixture volume of $150 \mathrm{I} \mathrm{ha-1}$. Right after the realization of the herbicide application, it was performed the first broadcast nitrogen fertilizing. In the following day, the area was flooded maintaining a water lamina of eight centimeters until physiologic maturation.

The realized evaluations were: phytotoxicity, initial stand, number of tillers, number of panicles, number of grains per panicle, weight of 100 grains and 
productivity. The phytotoxicity was visually evaluated at seven, 14, 21 and 28 days after the herbicide application (DAH), through the attribution of grades based in a percentage scale of 0 to $100 \%$, where zero corresponds to the absence of injuries and 100 to the plants death.

The initial stand was determined at 10 days after emergence (DAE), through the counting of the number of plants in one meter of the sowing line. In this local, it was determined the number of tillers and panicles per square meter, and from the collecting of 10 panicles in sequence in the sowing line it was determined the number of grains per panicle and mass of hundred grains.

In order to evaluate the grains productivity it was realized a manual harvest of the utile area of each plot $\left(4,76 \mathrm{~m}^{2}\right)$ when the grains achieved mean humidity of $22 \%$. This material was trashed, weighted and its grains humidity at harvesting determined, being the last one corrected to $13 \%$ for the yield estimate.

The data obtained were analyzed in order to attend the presuppositions of the variance analysis (normality and homocedasticity $p \leq 0,05$ ), and transformed when necessary. In case of significance of the treats effects, it was applied the Tukey test $(p \leq 0,05)$ for the comparison of herbicide dressings means, and applied the test $(p \leq 0,05)$ for the comparison of sowing periods.

\section{RESULTS AND DISCUSSION}

Experiment 1- Effect of the dissimilar seed dressings in the physiologic potential of irrigated rice seeds.

There was interaction between the factors seeds dressings and temperature. In the conditions that the rice seeds were 6gsubmitted, it was observed that the seeds dressing influenced the initial development of seedlings at the temperatures of 25 and $17^{\circ} \mathrm{C}$.

In relation to the germination, there was significant difference among temperatures and, when the seeds were submitted to optimal temperature $\left(25^{\circ} \mathrm{C}\right)$ the differences between the products and the control (no dressing) became less expressive. Only the dressings with dietholate and the combination of dietholate + fipronil + carbonxina + tiram differed from the rest, resulting in lower germination values. When submitted to cold stress $\left(17^{\circ} \mathrm{C}\right)$, the effect of seeds dressing became more visible, having difference among dressings.

The dressing containing GA3 stood out in the seeds germination when the same was submitted to temperature of $17^{\circ} \mathrm{C}$. It can possibly occurs because of the hormone effect, considered endogenous enzyme activator, in the germination uniformity.

The use of growth regulators, as gibberellin and cytokinin, in the germination stage, can improve the performance of seeds from diverse species, mostly under adverse conditions (Dubal et al., 2016; Troyjack et al., 2017). This factor is observed in the results obtained when the seeds were under low temperature stress $\left(17^{\circ} \mathrm{C}\right)$, however, the influence of GA3 in the seeds germination depends on the species.

In the evaluation of germination on the two temperatures, the application of tiometoxam insecticide did not present difference in relation to the treat no application of seed dressing (control). According results presented by Almeida (2011), in controlled conditions, in which were used different rice cultivars, including the cultivar IRGA 424, and it was evaluated the physiologic performance of rice seeds with the tiametoxan application, the results demonstrated favoring of the physiologic quality of seeds. 
It was observed that the use of dietholate negatively interfered in the germination and first germination counting, at $25^{\circ} \mathrm{C}$ and at $17^{\circ} \mathrm{C}$, when used in an isolated manner or combined with insecticide and fungicide. This combination is commonly used by most producers, although, in the germination test, this was the most harmful treat in the germinating process of both temperatures.

According to Deridder et al. (2002), the seeds protectors increase the cereal tolerance to chemical products through physiologic mechanisms. The protector effect of the dietholate is related to the increase of the glutathione enzyme expression Stransferase (GSTs), causing alterations in the plant by the activation of reactions of oxidation, reduction and hydrolysis. Subsequently, the reduction of the germination possibly occurred due to the alterations in the metabolism of seeds dressed during the germination stage.

For the treat composed by the combination of the products dietholate + fipronil + carboxina + thiram, there was reduction in the germination percentage carried out in low temperature $\left(17^{\circ} \mathrm{C}\right)$ and optimal temperature $\left(25^{\circ} \mathrm{C}\right)$. Possibly, there was interaction of the applied products, causing reduction of normal seedlings, allied to the stress by low temperature (Mertz, et al., 2009).

The gibberellic acid was the treatment that more affected vigor, being shown in the first germination counting, at five DAS, mostly when submitted to temperature of $17^{\circ} \mathrm{C}$. The stimulus to germination with gibberellic acid is due to the fast synthetizing of hydrolytic enzymes in response to the presence of the GA3 hormone. These enzymes are transported to the aleuronic chamber of the seed, responsible for the conversion of starch in sugar, therefore being used in the new plant growth (Schwechheimer, 2008).

According to the results obtained, there was an increase in the initial development of rice seeds with the GA3 applying, represented by the evaluation of first counting of germination. The use of growth regulator for seeds dressing can positively influence the development of rice seedlings, assisting the initial establishment of seedlings submitted to stress.

Besides being considered a cultivar with good adaptation to conditions of low and medium temperature in tests of sensibility to cold, the cultivar IRGA 424 presented survival of only $2.5 \%$ of seedlings in the study developed by Cruz et al. (2010).

It is worth to highlight that when germination is elevated, this results will not guarantee similar performance afterwards, since it depends on the physiological potential and environment conditions.

In the evaluation of the first counting of germination at $25^{\circ} \mathrm{C}$, the treatments tiametoxam, fipronil and carboxina+thiram did not differ among themselves. In the other hand, the dressing with dietholate and he combination of dietholate+fipronil+carboxina+thiram reduced the germination percentage, due to the sensibility of the dressed seeds, which contributed to the loss of vigor. The same occurred in the temperature of $17^{\circ} \mathrm{C}$, when the treats tiametoxam, fipronil+carboxina+thiram and control did not differ among themselves. However, there was a significant decrease in the normal seedlings in this evaluation for the treats dietholate e dietholate + fipronil + carboxina + thiram.

One of the techniques used to estimate the seeds vigor is the index of germination velocity, being the faster germination the higher vigor (Lima et al., 2005; Monteiro et al., 2016). The results obtained in this study allows to infer that the application of seeds dressing increase the initial establishment of rice seedlings submitted to temperature of $25^{\circ} \mathrm{C}$, when compared to seeds with no dressing. It was 
observed that the treats tiametoxam, fipronil, GA3 and carboxina+thiram did not differ themselves.

The seeds received the dressing with dietholate and the combination dietholate + friponil + carboxina + tiram, presenting reductions in the vigor. It occurs possibly, because seeds possess some sensibility degree to the use of products, which contributes to the reduction in vigor. Besides, other hypothesis is that the using this protector in seeds decrease the velocity of water absorption, which is indispensable to trigger off metabolic and biochemical processes of the germination, occasioning, thus, reduction of the index of germinating velocity (IVG).

The control treat (no dressing) thiametoxam, dietholate, fipronil $e$ carboxina+thiram, and no dressing did not present significant difference in the temperature of $17^{\circ} \mathrm{C}$. According to Almeida et al. (2009), the tiametoxam, among the tested treats, stimulated the physiologic performance of carrot seeds submitted or not to hydric stress, although, in other stress conditions (temperature), these results were not observed.

The cold test is based in the evaluation of seeds quality under adverse conditions of temperature, the results of the cold test, where for the temperature of $25^{\circ} \mathrm{C}$, the control treat did no differ from the dressing with GA3 and carboxina + thiram, demonstrating similar results to the percentage of normal seedlings. The dressings tiametoxam, dietholate and fipronil did not differ from themselves. For the combination of dietholate + fipronil + carboxina + thiram there was reduction of normal seeds, differing from the other treats, therefore being the treatment that has influenced the more in the vigor of rice seedlings.

For the combining of dietholate + fipronil + carboxina + thiram there was a decrease in the vigor for the cold test in the temperature of $17^{\circ} \mathrm{C}$. Such fact can be explained, possibly, for the occurrence of interaction among the products, being other possible hypothesis for seed primarily metabolize the product, spending energy. It causes a deficit of energy for the plant growth (Salgado et al., 2013), allied to conditions where the seeds are submitted to the temperatures of cold test.

The accelerate aging test consist in the exposure of seeds in conditions of elevated humidity and temperature, process that cause deteriorative effect and reduce the sugar content of the seeds (Marcos Filho, 2015). Evaluating the effect of the seeds dressing, in the accelerate aging test, the results did no differ from the other observed results, highlighting the negative effect when the seeds received the dietholate product, evidenced in the temperature $25^{\circ} \mathrm{C}$, and mainly in the combination dietholate + fipronil + carboxina + thiram under $17^{\circ} \mathrm{C}$. When the seeds were exposed to stress conditions (low temperature), after passing thru a deterioration process such as the accelerate aging test, the dressing with gibberellic acid demonstrated efficiency, making expressive the percentage of normal seedlings.

There was an increase in the shoot length in seeds dressed with gibberellic acid. These results were also found in diverse rice culivars, by Flores et al. (2002), where the action of GA3 in seedling stage found significant differences in their length.

The reduction of the growth suggests the existence of the sensibility of rice seeds to the protector studied, since the treatment that possessed dietholate inhibited the initial growth of the shoot of seedlings in two tested temperatures. Similar results were obtained in sorghum, using seeds protector flurazole, which induced the inhibition of the seedlings growth (Hirase \& Molin, 2003), in rice, with the protector diethyl phenyl phosphorothioate (Mistura, 2008).

When submitted to stress conditions, there was difference among treatments. The control treat, tiametoxan, fipronil, GA3 and carboxina + thiram, did not differ from 
themselves. The dressing with the combination of dietholate + fipronil + carboxina + thiram reduced the root length, not differing from the control treats, fipronil and GA3. The use of gibberellic acid, even positively influencing the other tests, did not affected the root length. Studies showed that the growth regulators do not present effect in the radicular system due to its function of develop the shoot growth, found in this present study in the temperature of $25^{\circ} \mathrm{C}$. However, Flores et a. (2002) observed positive effect of GA3 in the root length of different rice cultivars.

For the evaluation of the dry matter of seedlings, there was difference between temperatures $\left(25\right.$ and $\left.17^{\circ} \mathrm{C}\right)$. At the temperature of $25^{\circ} \mathrm{C}$, repeatedly the combination of products (dietholate + fipronil + carboxina + thiram) with the control treatment, presented difference among the other dressings, being these the lowest values. The difference between dressing and the control became less evident for the test at the temperature of $25^{\circ} \mathrm{C}$. In relation to the seeds submitted to temperature of $17^{\circ} \mathrm{C}$, the seeds that received the treats with dietholate and the combination of the same with fungicide and insecticide, also represented a decrease of the dry matter mass of seedlings.

Experiment 2 - Effect of seeds dressing in the initial establishment of irrigated rice in different sowing periods

For the phytotoxicity there was interaction between the applied treats herbicides and between sowing periods, not having effect of seeds dressing. To the evaluations of phytotoxicity before the recommended period (1은 Season), at 14 and 21 days after herbicide applying, there was difference between herbicides. The data of the evaluation of phytotoxicity at 28 days after herbicide applying were not presented, since the crops did not showed toxicity signs caused by herbicides.

This result was also observed by Martini (2014) that at seven and 28 days after application, also did not observed toxicity injuries in the rice crops when sowed before the recommended season, being used some herbicides, among them the bispiribaque-sodium.

Some factors may affect the relation between phytotoxicity and temperature, such as the evaluated vegetal species, detoxification rate and the used herbicide (Mccullough e Hart, 2006). The herbicide bispiribaque-sodium was the one that presented higher phytotoxicity in relation to the control and to profoxidim in the $1^{\text {o }}$ sowing season. At the phytotoxicity evaluation of rice crops, when sowed in recommended period ( $2^{\circ}$ Season), there was higher phytotoxicity of the inhibitor herbicide ACCase, at seven and 14 days after the herbicide applying compared to the control. At 21 days after application, it was not found difference among herbicides in the same season (October). When the evaluations are observed at field, the adverse conditions are fundamental for the results, as temperature, solar radiation and precipitation.

The air temperature is one of the main environmental variables to be observed in the moment of herbicide applying, mostly for the applying of ACCase herbicides, related to the culture and weed control.

This effect was observed by Medd et al., (2001), where it was evaluated the effects of maximum air temperature at the applying day and sum of daily minimum air temperature of seven days before the clodinafop-propargyl applying. It was instated that the conditions of low air temperature at the moment or after the herbicide applying delayed the answers in Avena spp. In the year that the experiment was conducted (2013/2014), the average temperature in the month of the dressing application was constant. It was observe that after the herbicide applying, the temperature and 
radiation, elevated and then decreased, when the culture was conducted before the recommended period (10 Season). In the other hand, the spread on of dressing in the recommended period ( $2^{\circ}$ Season), the mean air temperature decrease and right after was elevated, although, the solar radiation elevated after the herbicide applying.

For the herbicides inhibitors of ACCase enzymes and efficacy is determined by the increase of air temperature, until certain limit. Stresses by low temperature increases the content of wax in leaves and decrease the plants metabolism, occasioning smaller product absorption and translocation (CIESLIK, 2013).

The rice selectivity to herbicides inhibitors of ACCase enzymes, in general, occurs in level of site of action, which means, through the insensibility to ACCase (OLIVEIRA Jr. 2011). For Dan Hess (1994), there is no difference among the absorption, translocation and metabolism between plant species.

Under elevated temperatures, it can occur reduction of the herbicides ACCase inhibitors, due to the higher detoxification (CIESLIK, 2013). The detoxification from herbicides by the crops affects the selectivity for the cultures and weeds conferred by detoxification of herbicides are generally associated with families of enzymes phytochrome P450 monooxygenases and glutathione-S-transferases (GSTs) (READE et al., 2004).

The possible explaining of the phytotoxicity at seven and 14 days after the herbicide dressing in the second season is due to the alterations of temperature among the applying day and days after it. The climate conditions in the period of herbicide dressing in the recommended season, where occurred days of low temperature, favoring the increase of symptoms and death of rice seedlings.

The possible physiologic alterations caused by temperature probably increased the susceptibility of the foliar tissue to herbicide action, increasing the product absorption in the applying day. With the posterior increase in temperature, the symptoms of phytotoxicity became more visible, causing chlorosis, necrosis and death of some plants. The luminous intensity affects the activity of herbicides inhibitors of ALS enzyme in crops (CAMARGO et al., 2012; MACIEL et al., 2011), although, the positive or negative effect are not clear in literature.

Besides being considered a fact of controversy effect, the solar radiation must be taken into account, in relation to absorption of herbicides inhibitors of ACCases. Normally, increased index of irradiation favors these herbicides activity (HATTERMAN VALENTI et al., 2006).

This factor can be evidenced in days after herbicides dressing, where there was expressive reduction and posterior increase of solar radiation ratio. The solar radiation ratio two days after the herbicide applying achieved approximately $200 \mu \mathrm{mol} \mathrm{m}-{ }^{2} \mathrm{~s}^{-1}$, this condition may have favored the surging of symptoms in rice plants, due to the possible detoxification reduction and unfavorable conditions for its metabolism.

After the herbicide applying, there was a reduction of the solar radiation ratio of approximately $600 \mathrm{cal} . \mathrm{cm}^{-2} \mathrm{dia}^{-1}$ to $200 \mathrm{cal}^{\mathrm{cm}} \mathrm{cm}^{-2} \mathrm{dia}^{-1}$, this condition can result in higher herbicide absorption.

On the other hand, studies with the herbicide 14C-imazetapyr in plants of red rice (Oryza sp.) tolerant to the herbicide, maintained in conditions of growth chamber demonstrated superior herbicide absorption in conditions of higher luminous intensity than in reduced radiation (CAMARGO et al., 2012).

The influence of solar radiation on the applying of herbicides inhibitors of ACCase enzyme was highlighted in studies with the Poaceae Setaria fabari. The crops were maintained under elevated luminous intensity $\left(812 \mu \mathrm{mol} \mathrm{m}^{-2} \mathrm{~s}^{-1}\right)$ presented fluazifop-P absorption of approximately $25 \%$ superior in comparison to those in 
radiation condition of $390 \mu \mathrm{mol} \mathrm{m}-2 \mathrm{~s}-1$ and $50 \%$ superior when compared to low light intensity (145 $\mu \mathrm{mol}$ m-2 s-1) (HATTERMAN-VALENTI et al., 2006).

The light affects some physiologic processes in plants, which influences the absorption and translocation of herbicides inhibitors of ACCase (HULL et al., 1982). Among other physiologic and morphologic factors, the elevated radiation favors the photoassimiliate synthesis, which is necessary to the herbicide transportation in the plant.

For the evaluation of the initial plant stand occurred difference among sowing seasons, although, there was no difference between the herbicides before the recommended season (1 Season). At the recommended season, there was difference between herbicides, being the profoxidim the herbicide that most reduced the initial stand of plants. After the rice sowing, realized in September, the minimum air temperature at the month stayed on average $11^{\circ} \mathrm{C}$ and the average maximum temperature did not crossed $16^{\circ} \mathrm{C}$, this condition of temperature stress remained until the next month, being the minimum and maximum temperature averages of $13^{\circ} \mathrm{C}$ and $17,5^{\circ} \mathrm{C}$ respectively, in the month of October.

This condition was prejudicial to the good initial development of the crops, though this fact might explain the difference between the evaluations of the initial stand between two seasons. When the sowing in the recommended season occurred (October) the period of exposition to low temperature was shorter, because the averages in the month of November were higher than anterior months.

In the evaluation of the tillers number, there was difference among sowing seasons and among herbicides to the first sowing season. The herbicide profoxidim differed from the control treat, not differing from bispiribaque-sodium. It is worth to pointing out the recovery of the plants that received the profoxidim dressing in the recommended season. This result might be attributed to the detoxification mechanisms, being capable of release itself from the herbicide effect (MARTINI, 2014). Other point is the ability of the rice plants to tiller, because it can compensate the lower stand through the emission of a higher number of stems.

The correspondent period between the seedling and emergence of rice plants before the recommended period, besides the occurrence of low temperatures, was badly affected by the excessive humidity conditions, factor that might have contributed to the reduction of the initial stand of rice crops. For the condition of precipitation, there was an increase of the rain volume in the month of October, which is the month that rice plants of the first season were in full development. The precipitation of the month of October was higher than the normal rain volume for the month. This condition might have contributed to the low development of rice plant. In the evaluation of panicles per $\mathrm{m}^{2}$, grains per panicle and weight of 100 grains, it was observed difference only between sowing seasons.

This result has strict relation to the grains yield at harvest. In general, the lower numbers of tillers in the first season, compared to the second season, resulted in lower number of panicles, fact that might be the explanation of the higher number of grains per panicle, making the plant to compensate this difference.

For the evaluation, it was observed direct relation between the plant stand, tillers number and number of panicles per $\mathrm{m}^{2}$, being the second season with higher panicles number, having as well, the higher plants population.

In experiment conducted by Martins Filho (2012) studying nitrogen applying, pointed out the increase of tillering of rice plants incrementing the number of panicles, and consequently, the final grain yield. 
The grain yield components of a crop encompass three factors: panicle number, number of grains per panicle and grains weight. In the second season, there was higher number of tillers, resulting in higher number of panicles, although, and lesser number of grains per panicle. Even with this result, the second season presented higher yield.

The observed results of lesser number of grains per panicle in the second season, weight of grains were higher, allowing inferring that these results explain the fact that the second season represents higher yield in relation to the first.

In relation to the productivity means, the obtained results demonstrated higher grain yield, in the recommended season (October) $11000 \mathrm{~kg} \mathrm{ha}^{-1}$, and the productivity before the recommended season was around $9000 \mathrm{~kg} \mathrm{ha}^{-1}$, and in this evaluation the herbicide factor had no statistic difference. The sowing season is one of the main factors that define that rice grains productivity. The choice of the ideal season is important and depends on plenty factors as, environmental conditions, soil type, cultivar and incidence of weed in the area. In the irrigated rice, the growth period is limited by the period in which the factors of temperature and solar radiation are available in enough amounts to allow the plant full development.

Based on the exposed, it can be inferred that the seed dressing with gibberellic acid positively influenced the rice seeds, in the optimal temperature $\left(25^{\circ} \mathrm{C}\right)$ and suboptimal temperature $\left(17^{\circ} \mathrm{C}\right)$. When the seeds were treated with $\mathrm{GA} 3$ in low temperatures, it positively influenced the seedlings vigor.

The treatment with dietholate and the combining of dietholate + fipronil + carboxina + tiram, negatively influenced the germination and the vigor tests in both temperatures, decreasing the physiologic performance of rice seeds in lab. When taken to field, the seeds dressing did not influence the analyzed factors, being dependent of the herbicide applying and the sowing season.

Given the climate conditions, the temperature was the factor that most influenced the culture phytotoxicity of the crop, being the herbicide inhibitor of ALS presenting higher toxicity, when sowed in beginning of September. At the sowing in the recommended season, the plants presented higher injuries symptoms when received dressing of herbicide inhibitor of ACCase.

Besides presenting phytotoxicity, the rice plants presented detoxification power from the herbicide, being possible to analyze this fact, since there was higher number of tillers, resulting in higher number of panicles resulting in higher productivities.

\section{REFERÊNCIAS BIBLIOGRÁFICAS}

AISENBERG G.R.; DALBERTO D.S.; KOCH, F.; CARVALHO, I.R.; DEMARI, G.H.; SZARESKI, V.J.; NARDINO, M.; SOUZA, V.Q.; PEDO, T.; AUMONDE, T.Z.; AGOSTINETTO, D. (2016). Effect of pre-emergent herbicides on the germination and initial growth of trifolium repens L. International Journal of Current Research, 3: 39600-39606.

ALMEIDA, A.S. et al. (2009). Bioativador no desempenho fisiológico de sementes de cenoura. Revista Brasileira de Sementes, 31: 87-95. http://dx.doi.org/10.1590/S010131222009000300010 .

ALMEIDA, A.S. et al. (2011). Bioativador no desempenho fisiológico de sementes de arroz. Revista Brasileira de Sementes, 33: 501-510. http://dx.doi.org/10.1590/S010131222011000300013. 
ALMEIDA, A.S. et al. (2013). Thiamethoxam: An Inseticide that Improve Seed Rice Germination at Low Temperature. Insecticides - Development of Safer and More Effective Technologies. Intech, 14: 417-425. DOI: 10.5772/53207

BRASIL. (2009). Ministério da Agricultura, Pecuária e Abastecimento. Regras para análise de sementes. Brasília, 399p.

CAMARGO, E.R. et al. (2012). Interaction between saflufenacil and imazethapyr in red rice (Oryza ssp.) and hemp sesbania (Sesbaniaexaltata) as affected by light intensity. Pest management science, 68(7): 1010-1018. https://doi.org/10.1002/ps.3260

CIESLIK, L. F. et al. (2013). Fatores ambientais que afetam a eficácia de herbicidas inibidores da accase: revisão. Planta daninha. 31(2): 483-489. http://dx.doi.org/10.1590/S010083582013000200026

CONAB. (2018). Arroz - Brasil. Acompanhamento da Safra Brasileira. Décimo levantamento. Disponível em: <www.conab.gov.br> Acesso em: Outubro de 2018.

CRUZ, R.P.; DUARTE, I.T.L.; CABREIRA, C. (2010). Inheritance of rice cold tolerance at the seedling stage. Scientia Agricola, 67(6): 669-674. http://dx.doi.org/10.1590/S010390162010000600008

DAN HESS, F. (1994). Modeofaction Lipid Biosynthesis Inhibitors (graminicides ACCa inhibitors). In: Purdue University, (Ed,). Herbicide Action Course. West Lafayette, EUA: CRC Press, 201-216.

DELLAGOSTIN, S.M.; BERNARDI, D.; NOBREGA, L.H.P.; DELLAGOSTIN, D.M.; CARVALHO, I.R.; DEMARI, G.H.; SZARESKI, V.J.; NARDINO, M.; LAUTENCHLEGER, F.; SOUZA, V.Q.; AUMONDE, T.Z.; PEDO, T.; ZIMMER, P.D. (2016). Physiological parameters applied to the soybean seed storage techniques. International Journal of Current Research, 8: 41523-41527.

DEMARI, GH.; SZARESKI, V.J.; CARVALHO, I.R.; PIMENTEL, J.R.; TROYJACK, C.; SANTOS, L.A.; OLSEN, D.; ROSA, T.C.; MENEGHELLO, G.E.; SCHUCH, L.O.B.; SOUZA, V.Q.; AUMONDE, T.Z.; PEDO, T. (2018). Chlorophyll content and seed vigor of upland rice in response to the addition of seed promoting treatments. Australian Journal of Crop science.

DERIDDER, B.P.; DIXON, D.P.; BEUSSMAN, D.J. et al. 2002. Induction of glutathione Stransferases in arabidopsis by herbicide safeners. Plant Physiology, 130: 1497-1505. DOI: $\underline{10.1104 / p p .010066}$

DUBAL, I.T.P.; TROYJACK, C.; KOCH, F.; AISENBERG, G.R.; SZARESKI, V.J.; PIMENTEL, J.R.; NARDINO, M.; CARVALHO, I.R.; SOUZA, V.Q.; VILLELA, F.A.; AUMONDE, T.Z.; PEDO, T. (2016). Effect of temperature on bean seed germination: vigor and isozyme expression. Agricultural Science Research Journals, 1: 001-009.

EMBRAPA. (2012). Sistema Brasileiro de Classificação de Solo. 2ª ed., Rio de Janeiro: EMBRAPA, $306 \mathrm{p}$.

FLORES, I.F. (2002). Tratamento de sementes com ácido giberélico e crescimento de plântulas de arroz (Oryza sativa L.). Revista da FZVA, Uruguaiana, 9: 73-78.

FREITAS, T.F.S. et al. (2008). Produtividade de arroz irrigado e eficiência na adubação nitrogenada influenciadas pela época de semeadura. Revista Brasileira de Ciência do Solo, 32: 23972405. http://dx.doi.org/10.1590/S0100-06832008000600018. 
HASHIMOTO, M; KOMATSU, S. (2007). Proteomic analysis of rice seedlings during cold stress. Proteomics, 7: 1293-1302. DOI: 10.1002/pmic.200600921

HATTERMAN-VALENTI, H. M.; PITTY, A.; OWEN, M.D. K. (2006). Effect of environment on giant foxtail (Setariafaberi) leaf wax and fluazifop-P absorption. Weed Science, 54: 607-614. https://doi.org/10.1614/WS-04-158R2.1

HIRASE , K.; MOLIN, W.T. (2003). Sulfur assimilation in plants weed control: Potential targets for novel herbicides and action sites of certain safeners. Weed Biology and Management, Stoneville, 3: 147-157. https://doi.org/10.1046/j.1445-6664.2003.00098.x

ISTA. (2005). International Seed Testing Association, 23 mar. Especiais. Acessado em 30 set. 2013. Online. Disponível em: <http://seedtest.org/en/seed-testing-international_content---1--1085.html>Acesso em: Maio de 2018.

KAVALCO, S.A.F.; CARVALHO, I.R.; NARDINO, M.; FOLLMANN, D.N.; BARBOSA, M.H.; SZARESKI, V.J.; ROSA, T.C.; DEMARI, GH.; KOCH, F.; AISENBERG, G.R.; GONZATTO, T.; PEDO, T.; AUMONDE, T.Z.; SOUZA, V.Q. (2017). Dual-Purpose wheat subjected to different seed treatments. Australian Journal of Basic and Applied Sciences, 11: $45-51$.

KEHL, K.; KEHL, K.; SZARESKI, V.J.; CARVALHO, I.R.; NARDINO, M.; DEMARI, GH.; ROSA, T.C.; GUTKOSKI, L.C.; PEDO, T.; AUMONDE, T.Z.; SOUZA, V.Q.; ZIMMER, P.D.;MENEGHELLO, G.E. (2016). Genotype environment interaction under industrial and physiological quality of wheat seeds. International Journal of Current Research, 8: 3846138468 .

KOCH, F.; ZIMMER, G.; MONTEIRO, M.A.; MARTINS, A.C.; DELIAS, D.S.; TROYJACK, C.; SZARESKI, V.J.; BORGES, E.G.; PEDO, T.; AMARANTE, L.; VILLELA, F.A.; AUMONDE, T.Z. (2017a). Chemical composition and physiological quality of wheat seeds with the application of trinexapac-ethyl, a plant growth regulator. Australian Journal of Crop Science. 11: 1527-1533. doi: 10.21475/ajcs.17.11.12.pne565

KOCH, F.; CARVALHO, I.R.; SZARESKI, V.J.; DEMARI, GH.; MONTEIRO, M.A.; PIMENTEL, J.R.; NARDINO, M.; PEDO, T.; SOUZA, V.Q.; AUMONDE, T.Z. (2017b). Ecophysiological responses of dual-purpose wheat originating from different cutting management systems. Semina Ciências Agrárias, 38: 1641. http://dx.doi.org/10.5433/1679-0359.2017v38n3p1641

LIMA, M.G.S. et al. (2005). Qualidade fisiológica de sementes de arroz submetidas a estresse salino. Revista Brasileira de Sementes, 27: 54-61. http://dx.doi.org/10.1590/S010131222005000100007

LILGE, C.G. et al. (2003). Desempenho de sementes de arroz de diferentes cultivares na presença do herbicida glufosinato de amônio. Revista Brasileira de Sementes. 25: 82-88. http://dx.doi.org/10.1590/S0101-31222003000400012

MACEDO, W.R; CASTRO, P.R.C. (2011). Thiamethoxam: Molecule moderator of growth, metabolism and production of spring wheat. Pesticide Biochemistry and Physiology, 100: 299304. https://doi.org/10.1016/j.pestbp.2011.05.003

MACIEL, C.D.G.; et al. (2011). Desenvolvimento de gramados submetidos à aplicação de retardadores de crescimento em diferentes condições de luminosidade. Planta Daninha, 29: 383-395. http://dx.doi.org/10.1590/S0100-83582011000200016 
MCCULLOUGH, P.E.; HART, S.E. (2006). Temperature influences creeping bentgrass (Agrostis stolonifera) and annual bluegrass (Poaannua) response to bispyribac-sodium. Weed Technology, 20: 728-732.

MARCOS-FILHO, J. (2015). Fisiologia de sementes de plantas cultivadas. 2.ed. Londrina: ABRATES, 660p.

MARTINI, L.F.D. (2014). Seletividade de herbicidas sobre a cultura do arroz irrigado em condições de estressepor frio. 118f. Tese (Doutorado em Fitossanidade)- Faculdade de Agronomia. Universidade Federal de Pelotas. Pelotas/RS.

MARTINS, J.M.C. et al. (2012). Relação entre rendimento de grãos e produção de panículas em cultivares híbridas de arroz submetidas a doses de $n$ na base e em cobertura. Revista Técnico Científica (IFSC), 3: 744.

MEDD, R. W. et al. (2001). Determination of environment specific dose-response relationships for clodinafop-propargylon Avena spp. Weed Resesearch, 41: 351-368.

MERTZ, L.M. et al. (2009). Alterações fisiológicas em sementes de arroz expostas ao frio na fase de germinação. Revista Brasileira de Sementes, 31: 254-262. http://dx.doi.org/10.1590/S0101-31222009000200031

MISTURA, C.C. et al. (2008). Influência do protetor de sementes dietilfenilfosforotioato sobre plântulas de arroz (Oryza sativa L.) Revista Brasileira de Agrociência. 14: 231-238. DOI: HTTP://DX.DOI.ORG/10.18539/CAST.V14I2.1906

MONTEIRO, M.A.; AISENBERG, G.R.; KOCH, F.; SALAU, G.M.; BEHENCK, J.P.O.; DEMARI, GH.; SZARESKI, V.J.; CARVALHO, I.R.; NARDINO, M.; SCHUCH, L.O.B.; PEDO, T.; VILLELA, F.A.; AUMONDE, T.Z. (2016). Yield and vigor of corn seeds under the influence of flooding periods. African Journal of Agricultural Research, 11: 3240-3245.

POPINIGIS, F. (1985). Fisiologia da Semente. Brasília: ABEAS, 289p.

READE, J.P.H.; MILNER, L.J.; COBB, A.H. (2004). A role for glutathione S-transferases in resistance to herbicides in grasses. Weed Science, 52: 468-474. https://doi.org/10.1614/P2002-168D

SALGADO, F. H. M. (2013). Maize seed germination treated with insecticides. Journal of Biotechnology and Biodiversity, 4: 49-53.

SCHWECHHEIMER, C. (2008). Understanding gibberellic acid signaling-are we there yet. Plant Biology, 1: 9-15.

SOSBAI - Sociedade Sul - Brasileira de Arroz Irrigado. XXXIII Recomendações técnicas da pesquisa para o sul do Brasil. Bento Gonçalves. 198p.

SZARESKI, V.J.; CARVALHO, I.R.; ROSA, T.C.; DELLAGOSTIN, S.M.; PELEGRIN, A. J. BARBOSA, M.H.; SANTOS, O.P.; SOUZA, V.Q.; PEDO, T.; AUMONDE, T.Z.; PEGORARO, C. (2018). Oryza wild species: an alternative for rice breeding under abiotic stress conditions. American Journal of Plant Sciences, 9: 1093-1104.

SZARESKI, V.J.; CARVALHO, I.R.; NARDINO, M.; DEMARI, GH.; PELEGRIN, A.J.; FERRARI, M.; FOLLMANN, D.N.; ROSA, T.C.; QUADROS, E.S.; PEDO, T.; ZIMMER, P.D.; SOUZA, V.Q.; AUMONDE, T.Z. (2016). Seeding rate and physiological quality of dual purpose wheat seeds. African Journal of Agricultural Research, 11: 4367-4374. 
SZARESKI, V.J.; CARVALHO, I.R.; NARDINO, M.; DEMARI, GH.; PELEGRIN, A.J.; FERRARI, M.; MEIRA, D.; QUADROS, E.S.; KEHL, K.; PEDO, T.; ZIMMER, P.D.; SOUZA, V.Q.; AUMONDE, T.Z. (2016). Ethyl Methane Sulfonate and its effects on morphological traits of dual - pourpose wheat. International Journal of Current Research, 8: 39707-39713.

SZARESKI, V.J.; CARVALHO, I.R.; KEHL, K.; LEVIEN, A.M.; NARDINO, M.; DELLAGOSTIN, S.M.; DEMARI, GH.; LAUTENCHLEGER, F.; VILLELA, F.A.; PEDO, T.; SOUZA, V.Q.; AUMONDE, T.Z. (2018). Evaluation of the adaptability and stability of wheat genotypes using a phenotypic index of seed vigor. Pesquisa Agropecuária Brasileira. 53: 727-735.

TROYJACK, C.; DUBAL, I.T.P.; KOCH, F.; SZARESKI, V.J.; PIMENTEL, J.R.; CARVALHO, I.R.; NARDINO, M.; DEMARI, GH.; LAUTENCHLEGER, F.; SOUZA, V.Q.; VILLELA, F.A.; AUMONDE, T.Z.; PEDO, T. (2017). Attributes of growth, physiological quality and isoenzymatic expression of common bean seeds produced under the effect of gibberellic acid. Australian Journal of Crop Science, 11: 1116-1122.

VILA-AIUB, M. et al. (2012). Glyphosate resistance in Sorghum halepense and Loliumrigidum is reduced at suboptimal growing temperatures. Pest Management Science, 69: 228-232. doi: 10.1002/ps.3464

WANAMARTA, G. D.; PENNER, D. (1989). Foliar absorption of herbicides. Weed Science, 4: 215-231.

YAZBEK JR., W.; FOLONNI, L.L. (2004). Efeito de protetor de sementes na seletividade de herbicida na cultura do algodoeiro (Gossypium hirsutum L.). Revista Ecossistema, 29: 3338.

ZANATTA, E.; SZARESKI, V.J.; CARVALHO, I.R.; PIMENTEL, J.R.; TROYJACK, C.; DELLAGOSTIN, S.M.; DEMARI, GH.; LAUTENCHLEGER, F.; SOUZA, V.Q.; MARTINAZZO, E.G.; VILLELA, F.A.; AUMONDE, T.Z. (2018). Pre-harvest Desiccation: Productivity and Physical and Physiological Inferences on Soybean Seeds During Storage. Journal of Agricultural Science, 10: 354. 